\title{
'I want to be a star': Doping technology and the incidence of performance-enhancing drugs among actors in Nigeria
}

\author{
Charles Emeka Nwadigwe \\ Theatre Arts Department \\ Nnamdi Azikiwe University, \\ Awka, \\ Anambra State, Nigeria \\ Email: chebenwa@yahoo.co.uk
}

\section{Introduction}

Drug and alcohol abuse has become an ever-increasing problem in Nigerian society with serious health and social implications. It has led to mental illnesses among young people and the deterioration of the health of the nation's active population. Drug and alcohol abuse contributes significantly to the incidence of domestic aggression, violent crimes, broken homes and juvenile delinquency in Nigeria (Ebie and Pela, 1981; Adelekan, 1991; Obot, 2004). Drug abuse now starts at an early age, particularly among street children. While young girls tend to abuse hypno-sedatives more than the boys, the reverse is the case for stimulants (Ebie and Pela, 1981). Observation shows that alcohol and cannabis appeared to be the more abused drugs in Nigeria before heroin and cocaine were added to the problem from the early 1980s. Indeed, substance abuse remains a serious crisis in Africa aggravated by abject poverty, wars, sociopolitical upheavals, and ineffective social welfare programmes across the continent.

In reaction to the substantial risk of drug abuse on the health of users and its attendant negative impact to the society, the Nigerian Federal Government set up the National Drug Law Enforcement Agency (NDLEA) and the National Agency for Food and Drug Administration and Control (NAFDAC) to combat the trend. These agencies, owing largely to official corruption over the years, made no appreciable impact in checking the trade and use of illicit drugs. A research study also found that NGOs and CSOs were not making the expected impact on drug demand reduction (DDR) in Nigeria because of poor funding and inadequate information on drugs (Obot, 2004). However, with the ongoing fight against corruption by the present Nigerian government, the agencies are beginning to perform, especially NAFDAC. But the incidence of drug abuse remains high among the urban poor mainly because the economic and social problems that lure people into drug abuse and addiction have not been significantly addressed.

The abuse of alcohol and other substances among performing artists is a serious crisis confronting drama school authorities, theatre workers and the general society in Nigeria. Drug abuse has led to various forms of accidents, crimes, and deviant behaviour on and off the stage, studio and movie locations. Its impact on the mental health of young and aspiring actors is producing alarming statistics by the day (Hagher, 2000, Nwadigwe, 2006). Indeed, many theatre trainees have become habitual users even before gaining admission into higher institutions of learning. But drug abuse in 
the Nigerian higher education sector is also not peculiar to the arts. There is currently a high and increasing rate of alcohol and drug abuse among medical students at Nigerian university campuses. Nevertheless, Hagher (2000) affirms that students in the performing arts, especially young actors, use alcohol and drugs in a bid to enhance their performance on stage. The problem is adversely affecting the education and professional development of performing artists in schools prompting research proposals to the Nigerian educational authorities to investigate the trend (Nwadigwe, 2006).

The link between the performing arts and youth delinquency generates a seemingly endless debate among scholars particularly on the relationship between the screen (television and films) and exhibition of deviant behaviour among its audience (Wilson, 1992). Besides the desire among many teenagers and youths to take alcohol and other drugs, the entertainment industry in general and theatre in particular appears to present an alluring motivation for young people to indulge in such acts. Two reasons can be adduced for the trend. First, the theatre is credited with the psychological power to move people's emotions. Thus, actors on stage, radio, television and in films are idolized as celebrities and young people tend to imbibe their performances as their own reality. They often accept as real and imitate the lives exhibited on stage and screen by the actors such as smoking, drinking, drug use, violence and romance depending on the predisposition of the viewer.

The second reason is that the art of acting, being a psychological and physical process, requires the creation of another realistic life through the body and brain as basic tools of the actor. But many performers, especially beginners, lack the skill and technique to accomplish such art with believability. Tucker (1994) affirms that inexperienced screen actors are lacking in technique, react badly to pressure and this hampers their performance. Many inexperienced actors suffer from performance anxiety or 'stage fright' and therefore turn to alcohol, stimulants and other drugs, albeit erroneously, to bolster their courage to face the audience. According to Hagher (2000):

Some inexperienced and uninformed actors commit the blunder of soaking themselves in alcohol and drugs in order to achieve what they believe is extra-special acting. These actors believe that drinking or drug-taking would enable them release inhibitions, to be able to say and do things they normally would be too inhibited to say or do. This unfortunate practice is very widespread among young actors world-wide.

The involvement of entertainers in drug abuse is a multidimensional phenomenon and a matter of global concern to professionals, regulatory agencies and health workers. According to McManus (2004), the use of performance enhancing drugs, regarded as the 'scourge of the professional athletic world', has been found to be spreading its ugly tentacles to the performing arts industry. Indeed:

The entertainment industry is particularly plagued with drug abuse. Top performers on the music scene often become involved with heavy drugs at some stage in their career. Many film stars are habitual drug users (Awake, 2001).

McManus (2004) also observes that it is not unusual for performers to suffer from performance anxiety, otherwise known as 'stage fright' and many performers turn to stimulants to reduce such performance-related anxiety for improved presentation. The prevalence of drug addiction and abuse in the performing arts has become so 
worrisome to American authorities that the NIDA began a programme to educate entertainers on the personal and social hazards of the phenomenon. The agency instituted the 'Prism Awards' for actors, directors and script writers in recognition of accurate portrayals of drug abuse and related violence in film and television (Cargo, 1997). A front runner for 2006 best Oscar, Phillip Seymour Hoffman, is currently engaged in a campaign against drug abuse. Hoffman had a spell in a rehabilitation camp in his early twenties, having been involved in drugs as a young fresh graduate from a New York drama school (Porter, 2006).

In Nigeria, young actors seeking to overcome anxiety and improve their performance have often resorted to stimulants even while undergoing training in theatre schools. This researcher has counselled a number of his students found taking narcotics and stimulants backstage before and during performances. The disturbing fact is that many of such performers develop a dependency on drugs, get involved in aggressive behaviour and crimes, suffer health complications and often induce their peers to join in the habit. This poses a significant menace not only to the image, professionalism and sustainability of the performing arts industry but also to the personal health of the victims and allied problems they cause to their families and the society.

\section{Methodology}

Purpose

The purpose of the study was to find out why some actors and actresses use performance enhancing drugs, in what circumstances the drugs and stimulants are used, the kinds of doping technologies and drugs they use, categories of performers that use such drugs and the effects of drug use during and after performance. The aim of the study is also to collect data direct from the artistes involved so as to help in suggesting effective and sustainable approaches to prevent or curb the trend.

\section{Study Site}

The site of this study is Onitsha, a large commercial city on the banks of the River Niger, in Anambra State, southeastern Nigeria. Onitsha is reputed to be 'the largest market town' in West Africa with an estimated population of 1.2 million (Maja-Pearce, 2001). The ever-increasing markets and industrial activities in the area have made Onitsha the destination of business people from various parts of Nigeria and the West African subregion. Since the recent rise of the Home Video industry in Nigeria, Onitsha has maintained a leadership role in the production and marketing of video films, picking up from where the popular 'Onitsha market literature' had left (Haynes and Okome, 1997; Maja-Pearce, 2001).

Indeed, the Upper Iweka market in Onitsha is a hub of video film production and marketing in Nigeria, feeding other major markets as the Idumota in Lagos, Sabon Gari in Kano, and Pound Road and Ariaria markets in Aba (Maja-Pearce, 2001). This potential has made Onitsha the meeting place of film producers, marketers and actors from different parts of Nigeria. The area and its environs also have rich forest and water resources and other natural features that continually attract film directors as locations for shooting. Stage productions are equally thriving in Onitsha and adjacent cities, 
promoted mostly by independent producers, marketing companies and theatre staff and students from the nearby University in Awka. Therefore, Onitsha is a veritable location to find actors and performing artists.

\section{Data Collection and Analysis}

Data for this study were gathered from in-depth interview schedules, focus group discussions and personal observations among actors in Onitsha, southeastern Nigeria. Participants in the study were recruited through the snowball technique. Having caught two of his students in the act of taking stimulants and drugs backstage, the researcher took them into his confidence and built a rapport with them. Another actor was involved in strange behaviour while on set at a film location. The researcher, being a member of the production crew, tried to assist the actor. In the process, the actor admitted taking some stimulants before coming to location. These three actors were interviewed independently and they became the key informants. They also helped to recruit and convince other actors who have used or currently use performance enhancing drugs and stimulants to participate in the interviews.

A total of 64 men and women ranging from 19-54 years in age were interviewed. The interview schedules lasted over a period of nine weeks and were arranged to give privacy and independence to the respondents. This was supplemented by Focus Group Discussions (FGD) involving a set of 16 respondents (an average of five participants per session). The interviews were conducted in the English language and where appropriate the Pidgin English dialect was used. Informants were met at rehearsal venues, theatres, studios and shooting locations. The venues for the interview sessions were subsequently arranged at the convenience of respondents. Some were interviewed at their homes, some at the rehearsal venues and others at their business offices to find out their opinions and experiences concerning stimulants and performance enhancing drugs.

In recognition of prevailing socio-cultural norms, a separate group discussion session was arranged for women. The Focus Group Discussion sessions enabled the researcher to compare the information obtained at the individual interview sessions with that of the groups. Respondents openly deliberated on the key facts at each session and this added validity to the findings. The interviews and discussion sessions were recorded on audio tapes and augmented with notes about respondents' non-verbal expressions. The tapes and notes were periodically reviewed with trained field assistants at the end of each interview session. The field assistants, however, did not participate in the actual interview sessions since the presence of 'strangers' could cause respondents to withhold some information. Research has shown that participants in deviant behaviour often withhold information or present false data to researchers whom they could not trust.

The interviews yielded a body of qualitative data which were organized according to thematic relevance for easier analysis. These themes are: notions of drugs and abuse, motivations for taking stimulants, categories of drugs, doping technologies and users, and impacts of drug use. 


\section{Notions of drugs and abuse}

All the respondents agree that drug abuse results from misuse or unauthorized use of drugs. However, there are divergent opinions on the definition of drugs. Fifty-five of the respondents argue that 'hard drugs' are harmful and identify such drugs as cocaine, heroine, marijuana, LSD and 'ICD'. They also claim that other drugs are 'mild' and do not cause much problem unless one takes an overdose of them. Ten of the respondents admit that they hear of substances, drugs and medicines but cannot really differentiate the 'harmful' ones from the 'harmless' ones. Eight respondents agree that all drugs are harmful whenever they are misused. However, the status of alcohol generated some interesting arguments and respondents hotly debated this point during the Focus Group Discussions. One of them simply identified as Teekay (aged 26) says:

I believe that alcohol is not really a problem as such even though it can intoxicate. If it is that harmful, why is it sold and consumed freely at every street corner in Nigeria? Why are NAFDAC (National Agency for Food and Drug Administration and Control) and NDLEA (National Drug Law Enforcement Agency) not arresting all those dealers and consumers? I think that over-consumption of anything, even water, is bad. That is the problem with drunks and alcoholics and not the drink itself. For me, those who cannot control their consumption should not take alcohol.

The interviews and focus group discussions generally reveal that many performing artists who use stimulants and intoxicants do not know the chemical properties of the drugs, their side effects as well as the actual risk they pose to their health and the society.

\section{Motivations for taking stimulants}

According to some respondents, stimulants help the user to be 'confident', 'high' and 'sharp', thereby overcoming 'shyness', 'fear' and 'timidity'. The respondents in this bracket are mostly young artistes who are relatively beginners in the act. An adolescent respondent (aged 19), who prefers to be called Iyke, has this to say:

I want to be a star. But, I am naturally shy. So, to go on stage and face a crowd, I need to take something to fire me up. Even at film locations, I find it hard to face the camera and crew without feeling jittery and messing up. But when I drink or smoke something, it helps me to get the courage I need to perform my role. Many times, I take a small bottle of strong gin with me and use it backstage from time to time. I am not the only one. Many artistes drink gin or smoke igb` (marijuana) before and during performances.

From the data gathered at the interviews and discussion sessions, it appears that older actors and actresses who use stimulants exert some measure of influence on the younger ones who often see them as role models. A respondent and veteran in the theatre industry (aged 51), who pleaded anonymity, claims he learnt to use intoxicants as a young man from older actors and musicians with whom he worked at the early stages of his performing arts career. He goes further to say:

We frequent bars before performance. During intermissions, the big stars retire backstage to 'cool off' as they used to say. They were famous artistes and I admired them. Some drink, some smoke different things, some chew leaves and some even take personal injections. They were quite generous and can share with anyone who showed 
interest. I guess I started taking hot stuff from that time. But it does not hurt me or spoil my show. It just makes me feel normal as I mount the stage or set to perform.

The mentoring influence of established performers over the younger ones appears to go beyond professional matters and inculcates a whole way of life. A respondent and notable Nigerian movie star, aged 54, whom for the purpose of anonymity we will refer to as Tippo, speaks in the affirmative:

The star syndrome is like a cult. Similarly, hero-worshipping is powerful. It is a culture. They idolize and glorify whatever habits the star indulges in, whether good or bad. For example, I am a chain-smoker and I drink a lot of alcohol. My doctors have warned me against the habit. Even now, I still experience health complications related to it. It is a personal problem I've been trying to deal with. It has nothing to do with my profession. They are habits I picked from the street as a youth. I grew up in a polygamous home with extreme poverty, neglect and frustrations. But some of my admirers, especially young actors, try to drink and smoke heavily whenever we meet; either to imitate or outdo me. When I tell the younger artistes that it is not good for them, they simply laugh it off. But surely, it affects them negatively during or after the performance unlike me.

Apart from the urge to perform well and be a celebrity, one of the motivations for the use of stimulants by performing artists is economic. This is common with female artistes as revealed during the interviews and FGDs. Many film producers offer attractive fees to induce actresses to perform intimate scenes or engage in some form of nudity. Owing to the nature of Nigerian society, many women reject such roles due to the scandals and stigma associated with it. But due to harsh economic conditions, the almost irresistible pay, and promise of future parts and benefits in other movies and modelling contracts, many women accept such roles. An actress that goes by the nickname, Kessy, aged 29, explains:

Many girls accept such romantic and nude parts because of the pay. Things are hard, there is no job and we are struggling to survive. It takes more than mere professionalism to take off your dress before strangers and face the camera. Those who did it in the past faced a lot scandal. The mass media also make it worse by reproducing the pictures. I know one girl who had her wedding engagement broken by her fiancé because of the part she played in a movie. For a decent woman to play such roles in our culture and environment, you need some stimulants to push you on. What you see on stage and screen is fiction. It is not real life. It is only a play. Everything ends on the set but many people don't understand it that way. We are not loose women; just trying to do a job and earn a living. After all, is it not better than going into the street to engage in prostitution?

A popular Nigerian actress, Cossy Orjiakor, reacting to media reports about her nude performances states: 'Anybody can fondle my boobs. There is nothing bad in those roles whether in Shattered Home, Outkast or any of the films I've appeared in, for God's sake! I'm interpreting the script the producers gave me...' (Orjiakor, 2002, p.12). Another erotic performer, Shan George, concedes that nude roles especially in the Nigerian film Outkast have made her 'popular' and richer (George, 2002, p.29). Similarly, Akobundu (2002) observes that money and drugs are associated with nudity in Nigerian movies.

Some male artistes also use drugs to help them develop hormones necessary for muscular build-ups. Some of these actors admire the physique of some popular 
Western movie stars and Rapp musicians and desire to be like them. According to Slow, a muscular actor and performing arts graduate aged 27 :

I like macho men. With a good muscular physique, you can always get a role in films especially action and romance films. I started by going to the gym to lift weights and build up my muscles. There I met some athletes and we became friends. One day, they showed me some drugs. I don't know the names of the drugs but the weightlifters said that they are anabolic steroids which help to enhance their performance at sporting events. I used the drugs and noticed that they helped to pump up my muscles and veins and I've been getting parts in movies since then. I believe I'll get a big contract soon. But the drugs are expensive and you have to use them often to be in top shape.

The motivations notwithstanding, there appears to be a general consensus among the respondents that frequent use of drugs can lead to addiction.

\section{Categories of drugs and users}

Data available from the interviews and FGDs indicate that the actors and actresses use assorted stimulants ranging from 'mild' to 'hard' drugs. Data supplied during the interviews indicate that performing artists use a variety of stimulants including Ephedrine, marijuana, cocaine, heroine, pemoline, alcohol, and traditional concoctions made from herbs, roots and sap of plants and trees. There are some other drugs that are used by artistes though respondents could not tell the brand names. Indeed, an interesting piece of information obtained during the interviews and discussions is that some users do not actually know the names and possible side effects of some of the drugs they used, particularly the steroids.

Some users in this category admitted that they used the drugs on the recommendation of their friends and peer groups who often peddled such drugs without labels or the product's literature. These categories of drugs, mostly in capsules and injectable forms were used at variable doses depending on the peddler's prescription and assessment of a client's body weight. Narrating his experience, a respondent called Skido says:

A friend introduced me to those drugs. Some were in capsules and others in injection vials. He told me how to use them. I bought it from him and used it as he told me. The next day he came around and I told him how I felt. He advised me to reduce the dosage since according to him, my body weight was lower than he estimated and it seemed I had a light brain. I reduced the dosage and felt better after sometime. But I didn't continue because being a jobless graduate I couldn't cope with the high cost.

During the FGDs, some of the respondents claimed that they had heard of such drugs as EPO, LSD, as well as other doping technologies as gene or blood doping and hormoneboosting surgeries which are often used by people in the entertainment industries. However, though none of them admitted undergoing any such surgery, they could not tell if any of the drugs they have used fall within the category of EPO or LSD.

On the whole, alcohol and marijuana appear to be the most abused drugs among the artistes interviewed. Virtually all the respondents including women admitted taking considerable quantities of alcohol, particularly before performance. On the other hand, 48 respondents (75 percent) admit using marijuana regularly or periodically. In addition, 7 respondents (11 percent) still use cocaine or heroine while five respondents (eight percent) use steroids periodically. Out of these five one is female. It also appears 
that artistes use a variety of drugs depending on the circumstances such as availability, cost and peer pressure. The users of performance enhancing drugs also cut across various age brackets from teenagers to very mature adults. Nonetheless, data obtained during the interviews show that youths and middle-aged artistes (19-45years) constitute the majority of users.

\section{Impacts of drug use}

The impacts of performance enhancing drugs on their users are varied and appear to be dependent on the individual body anatomy of users and nature of drugs used. Data from the interviews show that performance enhancing drugs helped the users to build mass and strength, increase oxygen delivery in tissues, mask pain, relax their nerves and brain, control their weight, and get stimulated to take action by breaking their inhibitions. Similarly, respondents reported a number of side effects after using the drugs. Such effects include acute headache, exhaustion, body aches, muscular spasms, dizziness, depression, sleeplessness (insomnia), eye redness and pain, loss of libido, drowsiness and general lack of interest. A male respondent (aged 24) who holds a diploma in dramatic arts and goes by the nickname Buddy narrates his first-time experience after taking performance enhancing drugs:

A friend gave me those tablets. It is called Pemoline. But he calls it P-tabs, because the letter ' $\mathrm{P}$ ' was written on the tablets. According to him, ' $\mathrm{P}$ ' is for power. He said the tablets would give me extra strength. I needed it because I was cast for a competitive role in a movie that demanded a lot of stamina. It worked well for me and I noticed that I was not tired easily. The directors and producers commended my performance. However, the next morning I was totally exhausted. My muscles and nerves were aching and my eyes were feeling as if grains of sand were in them. I couldn't do any work. I had to take some pain killers and lie in bed. The feelings began to subside after two days.

Another respondent, Fredo (aged 28), admitted having 'unpleasant feelings' after taking some performance enhancing drugs which he could not identify at the time of the interview. He says he felt 'edgy' and 'impatient', lost his temper at a movie location and physically assaulted an actress for being 'rude'. The most alarming after-effect according to Fredo was 'the apparent loss of sexual feeling' as he 'could not have an erection for about three days' though he felt better in subsequent days.

Some common features among these respondents were the tendency to follow the recommendation of their peers and reluctance to consult trained medical personnel. Some of the respondents admitted using the drugs again despite the side effects. A female professional dancer and choreographer (age undisclosed) who prefers to be called IT, admitted using some LSD and amphetamine which give her extra energy to dance. She concedes that the drugs have some side effects such as 'exhaustion, nervousness, numbness at the nipples and finger tips' but observes that the feelings subside and disappear with time. Another female respondent, called Love, says her first experience at drinking alcohol before performance was influenced by her friend. But she noticed that it deadened her synaptic responses as well as cognitive and physical ability. Though she felt confident she was equally dizzy, drowsy and tired. According to Love, she had to lie to the director that she was ill and was excused to go home while her double went on stage for the night's show. 


\section{Discussion}

The use of drugs to enhance performance is becoming entrenched among performing artists. This ranges from non-habitual to habitual use which often leads to addiction. Available data indicate a tendency among such drug users to adopt various forms of doping technologies such as oral applications (ingestion), intravenous and intramuscular applications (injections) as well as nasal applications (smoking and sniffing or inhalation). The use of more advanced doping technologies such as blood doping or gene doping and surgeries was not found among the sample population although a number of respondents have knowledge of it especially as used by top-class athletes.

The motivations for using dope is mainly to enhance performance by masking pain, increasing oxygen delivery, building bone and muscles, stimulating, relaxing and controlling the weight of users. A majority of young artistes that use performance enhancing drugs were influenced by peer groups while others imitate the lifestyles of super stars that they admire as their idols or role models. Anxiety and the urge to overcome 'stage fright' (performance anxiety) is also a major cause of doping among young actors in Nigeria. Such beginners in the dramatic arts often start with alcohol, graduate to amphetamine, opium and other narcotics and may advance to steroids.

Furthermore, a level of ignorance appears to exist among users of performance enhancing drugs particularly in the area of risk awareness. The notion of what constitutes illicit drugs seems debatable among users. Similarly, the awareness of the personal health hazards and social consequences of drugs among the users appears superficial. Thus, most users do not seem to consider the potential harm of such performance enhancing drugs until they become addicted. A handful of users who are aware of the risks obviously consider the expected benefits as outweighing the hazards thus adopt the Machiavellian principle of 'the end justifies the means'.

Besides the social impact of drug addiction such as crime, maladjustment, aggressive attitudes, violence, broken homes, and assorted deviant behaviour, performance enhancing drug users also suffer personal health problems associated with adaptability, nervous and mental breakdown, cell damage, bronchitis and cancer. The users of performance enhancing drugs seem to be aware of the illicit nature of the act and are thus reluctant to consult doctors. Instead, many of them often resort to selfmedication in managing complications arising from the drugs they use.

There is a link between economic hardship and addiction to performance enhancing drugs in Nigeria. The high level of poverty and youth unemployment in the country places several graduates and skilled persons in a desperate struggle for the few available jobs. In the entertainment industry, the situation appears worsened by the weak legal system that allows non-professionals in search of glamour, fame and wealth to invade and hijack the industry. Thus, artistes are under intense pressure to get contracts and survive and such contracts depend on a track record of superlative performances. To some actors and actresses therefore, doping in all its ramifications is a survival strategy, a means to an end. The economic motivation often supersedes other considerations for users of drugs particularly in the negotiation of risks to personal and community health and security.

The ready availability of performance enhancing drugs on the streets of Onitsha (the study area) is indicative of weak law enforcement machinery. Users of narcotics 
and other heavy drugs obtain their supplies freely from peddlers and several joints in the locality. Nigeria has two specialized drug regulation agencies, the National Drug Law Enforcement Agency (NDLEA) and the National Agency for Food and Drug Administration and Control (NAFDAC). They are charged with the responsibility of checking drug abuse with the assistance of other law enforcement agencies. However, the more active of these agencies, the NAFDAC, appears to have lost the battle against illicit drug trade in Onitsha. Apparently frustrated by the brazen impunity enjoyed by drug barons due to their immense influence and criminal network, the NAFDAC and WHO recently declared Onitsha a drug disaster area (Ekeoba, 2006). The NAFDAC boss has escaped a number of assassination attempts from criminals believed to be agents of drug barons based in Onitsha. Indeed, the high level of crime and the violent activities of hoodlums, miscreants and ethnic militia on the streets of Onitsha have been linked to the booming trade and flagrant consumption of drugs and narcotics (Okoli, 2003). The flourishing trade in narcotics in Nigeria is mainly driven by commercial gains (Alubo, 1985). The ready availability of drugs is a key factor in its consumption and this is the case in Onitsha.

\section{Conclusion}

The incidence of drug addiction and abuse to enhance performance is rising among actors in the entertainment industry and this manifests itself in the adoption of different doping technologies to achieve desired results. The phenomenon, from the findings of this study, is prevalent among different categories of performers in the Nigerian theatre and motion picture industries. But the attention of authorities and the media is often focused on athletes in the sports sector with relative neglect of performing artists. Nevertheless, the risk posed by drugs to personal health and societal well-being remains substantial. The ripple effects of such risks can be better recognized by the fact that such actors are seen as superstars on stage, television and films and thus adopted as role models particularly by young people who idolize them.

Peer influence, a weak legal system, poverty, and youth adventurism and delinquency contribute in perpetuating drug abuse and its flourishing trade. There is therefore a dire need to review the legal codes and enforcement machinery as they apply to drug sale and consumption in Nigeria. The drug regulatory authorities must also turn their searchlight on actors, dancers and musicians to curb the rising incidence of performance enhancing drugs in the entertainment industry and its ripple effects on the society. The Nigerian anti-drug and regulatory agencies (NAFDAC and NDLEA) should borrow the approach of NIDA in USA by getting involved in the promotion of drug-free performances by artistes through awards, sponsorships and incentives to discourage doping in the industry.

Alcohol and drug abuse is a national problem that affects the health, development and future of the citizens and the society. While drug abuse now starts at an early age, it appears to mature and reach its climax when such youths enter the higher institutions of learning. A systematic programme of drug education and counselling should be mapped out by theatre and drama schools and incorporated into the curriculum to educate trainees on the personal and social hazards of performance enhancing drugs. The fight against alcoholism and drug abuse in general really needs an extensive approach beginning from the cradle to the class and beyond. 
Since the theatre is a purveyor of culture, Goodman and de Gay (2000) in their editorial notes maintain that theatrical performances should continue to be a symbol of a people's positive values and cultural identity. Thus, it can be used as a potent medium to fight drug abuse on campuses. However, a performer who indulges in such negative behaviour can rarely be an effective tool for its eradication in his community. Efforts must therefore be made by all stakeholders to ensure that the performer's conduct, on and off the stage or set, does not portray negative values and deviant culture. Finally, the various guilds in the performing arts and film industries in Nigeria should enact strict anti-doping regulations for members and enter into partnerships with drug enforcement agencies to combat the trend among artistes and save the profession and society from imminent disaster.

\section{References}

Adelekan, M. L., 1991, 'Drug abuse in Nigeria: an overview', Nigerian Journal of Educational Foundations 2(2): pp.149-155.

Akobundu, D., 2002, 'Nigerian movies and nudity', Saturday Punch, 8 June.

Alubo, S. O., 1985, 'Drugging the people: pills, profits and underdevelopment in Nigeria', Studies in Third World Society (24), pp.89-113.

Awake Magazine, 2001, 'Drugs: why do people abuse them?' Available at: http://www.watchtower.org/library/g/2001/7/8/article02.htm, accessed 26 February, 2006.

Cargo, S., 1997, 'Prism Awards recognize accurate portrayals of drug abuse and violence in films and TV', NIDA Notes 12 (5). September-October.

Ebie, J. C. and Pela, O.A., 1981, 'Some sociocultural aspects of the problem of drug abuse in Nigeria', Drug and Alcohol Dependence 8 (4): pp.301-306.

Ekeoba, F., 2006, 'WHO blacklists Onitsha over fake drugs', Nigerian Tribune, 23 October.

George, S., 2002, 'Outkast made me popular', Sunday Punch, 26 May.

Goodman, L. and de Gay, J., eds., 2000, The Routledge Reader in Politics and Performance, London and New York: Routledge.

Hagher, I., 2000, 'The actor in perspective', in I. Hagher, ed., Theatre and Stage-Craft in Nigeria, Abuja: Supreme Black Communications, pp.14-25.

Haynes, J., and Okome, O., 1997, Nigerian Video Films, Jos: Nigerian Film Corporation.

Maja-Pearce, A., 2001, 'Onitsha home movies', London Review of Books, 23 (9), 10 May.

McManus, D., 2004, 'Performance enhancing drugs?', Partial Observer, 27 September.

Nwadigwe, C. E., 2006, 'Drug abuse in the university environment: implications for sustainable theatre studies in Nigeria', Research proposal submitted to the Nigerian Educational Research and Development Council (NERDC), Abuja.

Obot, I. S., 2004, 'Responding to substance use problems in Nigeria: the role of civil society organizations', Substance Use and Misuse 39(8), pp.1287-1299.

Okoli, A., 2003, 'NDLEA impounds over 268 kilos of narcotics in Onitsha zone', Vanguard, 14 April.

Orjiakor, C., 2002, 'Anybody can fondle my boobs', Sunday Tribune, 17 March.

Porter, B., 2006, 'Hoffman talks about drug abuse', News24.com, Available at: http://www.news24.com/News24/Entertainment/Abroad/0112-1225-1243_1882972, 00.html, accessed on 26 February, 2006.

Tucker, P., 1994, Secrets of Screen Acting, New York and London: Routledge.

Wilson, S. R., 1992, Mass Media/Mass Culture, $2^{\text {nd }}$ Edition, New York: McGraw-Hill, Inc. 